\title{
PROBLEMATIKA IMPLEMENTASI PENDEKATAN SAINTIFIK KURIKULUM 2013 DALAM PEMBELAJARAN BAHASA JEPANG KELAS X IPB DI MAN X
}

\author{
S.Ulfa ${ }^{1}$, K.E.K.Adnyani ${ }^{2}$, D.M.S.Mardani ${ }^{3}$ \\ 123 Jurusan Pendidikan Bahasa Jepang, Universitas Pendidikan Ganesha, Singaraja,Bali \\ e-mail: saufaab@gmail.com krishna.adnyani@undiksha.ac.id \\ desak.mardani@undiksha.ac.id
}

\begin{abstract}
Abstrak
Penelitian ini bertujuan untuk: mendeskripsikan problematika implementasi pendekatan saintifik Kurikulum 2013 dan upaya yang dilakukan guru dalam mengatasi problematika pada pembelajaran bahasa Jepang kelas X IPB di MAN X. Data hasil penelitian akan dianalisis menggunakan metode deskriptif kualitatif dengan jenis penelitian studi kasus. Subjek penelitian alah guru bahasa Jepang dan objek penelitian adalah siswa kelas X IPB. Metode pengumpulan data adalah observasi, wawancara dan dokumentasi. Intrumen penelitian menggunakan pedoman observasi, pedoman wawancara dan RPP. Problematika yang dihadapi guru berkaitan dengan perencanaan pembelajaran, pelaksanaan yang meliputi kegiatan mengamati, menanya, mengolah informasi/mencoba, mengasosiasi/menalar dan mengkomunikasi, serta problematika dalam evaluasi/penilaian. Guru mengupayakan problematika tersebut dengan mengacu pada RPP sekolah lain dan dikondisikan sesuai yang terjadi dilapangan, menggunakan kartu huruf dan gambar, memberikan pertanyaan, mengulangi pelafalan bahasa Jepang dan tanya jawab.
\end{abstract}

Kata kunci: Pendekatan Saintifik, Kurikulum 2013, bahasa Jepang

要旨

本研究の目的は、科学的根拠に基づく2013カリキュラムをどのように実践しているか、当校日本語 授業において科学的根拠に基づく2013カリキュラムを実践する上での問題点を指導者がどう解決し ているかを明らかにすることである。本研究は、定性的記述法により分析した。対象は、日本語指導 教師及び生徒である。データは、観察、インタビュー、録撮影によりそれぞれの解説書、教案を参考 に収集した。本研究の結果、先生は自分の教案を作りない、結果、教師は、授業において解説、質問 、情報授受、共同作業、コミュニケーションにより2013カリキュラムを実践している

と評価は最大ある方法でない。当校言語コ...ス 10 年生の計画、実装と評価の性格を見つける。教師 は、教案をもとめる、かたかなとひらがなのカードとえカードを使用する、質問を上げる、日本語の 発音をくりかえすとシツモンとこたえをする。

キーワード : 科学的根拠、2013カリキュラム、日本語

\section{Pendahuluan}

Undang-Undang Nomor 20 Tahun 2003 tentang tujuan pendidikan nasional adalah untuk menumbuhkan potensi peserta didik agar manusia yang beriman dan bertakwa kepada Tuhan Yang Maha Esa, berakhlak mulia, sehat, berilmu, cakap, kreatif, mandiri, dan menjadi warga Negara yang demokratis serta tanggung jawab. Dalam menggapai tujuan pendidikan tersebut, tentu tidak bisa terlepas dari kurikulum pendidikan.

Kurikulum di Indonesia mengalami beberapa perubahan sejak diterapkannya kurikulum yang pertama yaitu Kurikulum 1947. Muhammedi (2016:49) menyatakan bahwa perubahan kurikulum terjadi karena adanya perbedaan dalam satu atau lebih komponen kurikulum antara periode tertentu yang disebabkan oleh adanya usaha yang disengaja. Selain Kurikulum 1947, kurikulum yang pernah digunakan di Indonesia adalah Kurikulum 1964, 1968, 1975, 1984, 1994, 1997, 2004, 2006, dan Kurikulum 2013.

Kurikulum 2013 merupakan program Menteri Pendidikan untuk menyempurnakan kurikulum yang diberlakukan sebelumnya yaitu KTSP 2006. Kurikulum 2013 dirancang untuk dapat mengembangkan seluruh ranah kompetensi yang dimiliki peserta didik yang mencakup kompetensi sikap (afektif), Pengetahuan (kognitif) dan keterampilan (psikomotor). 
Kurikulum 2013 memiliki ciri khas tersendiri yaitu adanya penerapan pendekatan saintifik atau ilmiah dalam proses pembelajarannya. Pendekatan saintifik menurut Kemendikbud memberikan konsep tersendiri bahwa pendekatan ilmiah dalam pembelajaran mencakup komponen yaitu mengamati, menanya, mencoba, mengolah, menyajikan, menyimpulkan dan mencipta (Seillariski. 2015:2).

Pendekatan saintifik merupakan proses pembelajaran yang dilakukan secara ilmiah. IImiah berarti proses pembelajaran tersebut dilakukan dengan menyesuaikan pada fenomena/fakta yang benar-benar terjadi. Selain itu, pembelajaran dengan menerapkan pendekatan saintifik menuntut siswa untuk aktif dan mandiri. Hingga saat ini pendekatan saintifik berbasis Kurikulum 2013 telah banyak diberlakukan di sekolah dari jenjang SD hingga SMA sederajatnya.

Bahasa Jepang merupakan salah satu mata pelajaran yang turut menerapkan pendekatan saintifik Kurikulum 2013. Bahasa Jepang dilaksanakan secara formal yang berkembang mulai dari sekolah menengah sampai perguruan tinggi. Menurut Rubin (2003:49) bahwa semakin berkembangnya bahasa Jepang tidak terlepas dari daya tarik perekonomian Jepang yang telah mendorong banyak pelajar untuk mempelajari bahasa Jepang.

Dalam menerapkan pembelajaran, terutama dalam implementasi pendekatan saintifik Kurikulum 2013, guru mengalami berbagai problematika. Sebagaimana yang diketahui berdasarkan observasi dan wawancara awal yang menyatakan bahwa problematika tersebut terdapat pada tahap perencanaan pembelajaran, implementasi dan evaluasi.

\section{Metode}

Penelitian ini mengangkat tentang suatu permasalahan yaitu tentang "Problematika Implementasi Pendekatan Saintifik Kurikulum 2013 dalam Pembelajaran Bahasa Jepang Kelas X IPB di MAN X" maka pendekatan yang digunakan adalah kualitatif. Pendekatan kualitatif dipilih karena akan mendeskripsikan implementasi pendekatan saintifik Kurikulum 2013 dalam pembelajaran bahasa Jepang kelas X IPB di MAN X.

Jenis penelitian ini menggunakan studi kasus dikarenakan pen elitian akan mengkaji secara rinci suatu latar, subjek, atau suatu tempat penyimpanan dokumen peristiwa tertentu mengenai problematika implementasi pendekatan saintifik Kurikulum 2013 dalam pembelajaran bahasa Jepang kelas X IPB di MAN X.

Subjek dari penelitian ini adalah guru bahasa Jepang. Sedangkan objek penelitian adalah siswa kelas X IPB.

Metode penelitian yang digunakan terdiri dari metode observasi, metode wawancara dan dokumentasi. Metode penelitian yang digunakan memerlukan intrumen pengumpulan data yang menjadi alat bantu yang dipilih dan digunakan peneliti dalam kegiatan mengumpulkan data agar kegiatan tersebut sistematis dan diperudah olehnya (Arikunto, 2006:101). Intsrumen yang digunakan terdiri dari pedoman observasi, RPP, dan pedoman wawancara (pendidik dan peserta didik).

Selanjutnya data hasil penelitian yang diperoleh akan dianalisis menggunakan prosedur analisis data deskriptif kualitatif yang terdiri dari reduksi data, penyajian data dan penarikan simpulan.

\section{Hasil dan Pembahasan}

Hasil yang diperoleh selama melakukan penelitian di MAN X bahwa guru bahasa Jepang belum secara maksimal mengimplementasikan pendekatan saintifik Kurikulum 2013 yang mencakup perencanaan, pelaksanaan dan penilaian/evaluasi.

Dalam tahap awal penerapan/implementasi Dalam tahap awal penerapan/implementasi pendekatan saintifik Kurikulum 2013 yaitu tahap pembuatan RPP, berdasarkan pada hasil wawancara, guru masih mengalami problematika. Problematika yang dihadapi guru adalah belum dapat menguasai teknologi dan beban biaya yang harus dikeluarkan guru jika menggunakan jasa orang lain dalam pembuatan RPP. Dampak yang dihasilkan adalah guru belum bisa membuat RPP secara mandiri. Karena problematika tersebut, guru berinisiatif menjadikan RPP dari sekolah SMAN $X$ yang dijadikan acuan untuk mengimplementasikan pembelajaran. RPP yang dijadikan acuan oleh guru bahasa Jepang di MAN X dipilih karena 
guru di SMAN X dikategorikan mampu dan ahli dalam pembuatan RPP Kurikulum 2013 dan seringnya melakukan pelatihan Kurikulum 2013.

Terkendala penguasaan teknologi menjadikan guru merasa kesulitan dalam pembuatan RPP yang seharusnya dibuat secara mandiri. RPP yang berasal dari SMAN $X$ tidak semua diaplikasikan dalam pembelajaran. Tentunya hal ini dikarenakan kondisi yang berbeda antara SMAN X yang berada di pusat kota dan MAN X yang berada di pedesaan. Untuk itu, guru bahasa Jepang mengaplikasikan apa yang ada dalam RPP dan tentunya disesuaikan dengan kondisi siswa dan sekolah serta lingkungan di sekitarnya.

Kedepannya, guru bahasa Jepang di MAN X harus membuat RPP secara mandiri dan disesuaikan dengan kondisi yang ada dilapangan. Adanya RPP akan memudahkan guru dalam mengaplikasikan/mengimplementasikan pembelajaran pendekatan saintifik dan menjadikan pembelajaran yang dilakukan lebih terstruktur, efektif dan efien. Hasil pembelajaran yang didapatkan siswa akan lebih maksimal dan mudah dalam memahami bahasa Jepang sesuai dengan apa yang diajarkan oleh guru.

Pendekatan saintifik yang dijadikan salah satu poin penting dalam penelitian karena berkaitan erat dengan Kurikulum 2013 yang diimplementasikan ke dalam pembelajaran bahasa Jepang di MAN X. Untuk itu, penelitian ini juga menyajikan bagaimanakah arti dari pendekatan saintifik serta langkah-langkah yang terdiri dari $5 \mathrm{M}$ yang dipahami guru. Berdasarkan wawancara, guru belum memahami arti dari pendekatan saintifik serta langkahlangkah $5 \mathrm{M}$ yang menjadi ciri khasnya. Guru mengatakan pula bahwa kedepannya bisa mempelajari pendekatan saintifik lebih dalam lagi. Hasil tersebut mengambarkan bahwa guru bahasa Jepang di MAN X masih berinisiatif mempelajari pendekatan saintifik terlebih pembelajaran yang diempunya sudah mengaplikasikan pendekatan tersebut.

Guru melakukan kegiatan pendahuluan dengan mengucapkan salam (Aisatsu), menanyakan kabar peserta didik dan melakukan absensi dengan menggunakan bahasa Jepang. Sebelum memulai ke inti pembelajaran, guru selalu mengulang materi yang sebelumnya diberikan dan menyampaikan materi yang akan dipelajari. Kegiatan tersebut selalu dilakukan selama observasi dilakukan. Perbedaan yang terjadi hanyalah pada observasi pertama, dimana guru membagikan hasil ulangan dan memberikan nasehat kepada peserta didik. Nasehat diberikan guru karena masih banyak siswa yang mendapatkan nilai rendah saat ulangan.

Kegiatan mengamati pada observasi pertama, guru menjelaskan terlebih dahulu materi tentang kata kerja golongan I, II, dan III dengan menuliskannya di papan tulis beserta contoh kata dan kalimat. Setelah menjelaskan tentang KK golongan I,II, dan III, guru melanjutkan materi tentang KK bentuk masu (ます), masen (ません), mashita (ました) dan masendeshita (ませんでした).

Observasi kedua, sebelum memulai pembelajaran, guru mengintruksikan siswa untuk mendengarkan apa yang akan dijelaskan terkait materi yang akan dipelajari tentang

“Keluarga diri sendiri (わたしのかぞく)”. Selanjutnya guru menjelaskan beberapa materi yang berkaitan dengan cara menyebutkan keluarga diri sendiri dengan kata, pola kalimat dan contoh kalimat dalam bahasa Jepang.

Kegiatan mengamati pada observasi ketiga, terlebih dahulu guru mengintruksikan salah satu siswa untuk menuliskan materi yang ada di buku Sakura I ke papan tulis mengenai "keluarga orang lain".

Selanjutnya, kegiatan mengamati pada observasi keempat dilakukan guru dengan menjelaskan materi tentang kegemaran/kesukaan. Guru menjelaskan secara lisan bagaimana menyatakan kegemaran/kesukaan dalam bahasa Jepang. Ketika ada poin penting, seperti kosa kata atau contoh kalimat, guru akan menuliskannya di papan tulis.

kegiatan mengamati yang dilakukan juga belum dinyatakan sesuai. Guru mengatakan dalam wawancara, berkaitan dengan inisiatif guru untuk menjalankan kegiatan mengamati sesuai standar Kurikulum 2013 dan tentunya sesui dengan kondisi di lapangan. Seperti menggunakan kartu huruf dan kartu gambar menggantikan penggunaan Power Point. Walaupun selama observasi tidak terlihat guru menggunakan kartu huruf dan kartu gambar, tetapi guru sudah pernah melakukan kegiatan tersebut sebelumnya. 
Kegiatan mengamati, selama menjelaskan materi di papan tulis, guru selalu menggunakan huruf 'romaji'. Problemati yang didapatkan dari hasil wawancara bahwasannya siswa akan merasa kesulitan ketika guru secara langsung menggunakan huruf hiragana dan katakana. Untuk itu, guru mengatakan, huruf romaji yang digunakan tersebut nantinya bisa diubah menjadi kana oleh siswa sendiri. Dengan cara itu, kemungkinan siswa bisa berlatih dan memahami huruf kana lebih dalam.

Kegiatan menanya secara keseluruhan memang belum dikatakan maksimal. upaya guru berjalan dengan menanyakan kembali kepada siswanya tentang hal yang berkaitan dengan materi yang saat itu dipelajari, guna menguji kemampuan siswanya tentang pemahaman akan materi tersebut.

Pada observasi pertama, setelah menjelaskan materi, guru memberikan tugas untuk membuat 1 kalimat tentang $\mathrm{KK}$ yang sudah dijelaskan dan dipelajari. Dari tugas yang diberikan, siswa membuat kalimat dan menanyakan kosakata yang belum diketahuinya kepada guru. Beberapa siswa bertanya tentang bahasa Jepang dari Voli, Basket dan Pasar. Kegiatan menanya yang dilakukan walaupun tidak runut dan berasal dari ketidakpahaman siswa dari kegiatan mengamati, tetapi tetap berlangsung sesuai dengan kondisi siswa. dalam hal ini, guru tidak membatasi siswanya dalam bertanya, sehingga kegiatan menanya dapat dilakukan kapan saja.

Pada observasi kedua, kegiatan menanya tidak dilakukan guru (guru tidak mengajukan pertanyaan dan siswa tidak ada yang bertanya). Karena kegiatan menanya tidak berlangsung, guru melanjutkan pelajaran dengan mengintruksikan siswa untuk membuat kalimat tentang jumlah keluarga diri sendiri dan setelah selesai dapat disalin di papan tulis.

Observasi ketiga, kegiatan menanya tidak berlangsung. Guru tidak mengintruksikan siswanya untuk bertanya dan siswa tidak ada yang mengajukan pertanyaan. Guru memberikan pertanyaan terkait keluarga orang lain dengan menanyakan kosa kata yang belum dijelaskan guru yaitu bahasa Jepang dari ‘Bibi dan Paman' orang lain. Siswa tidak ada yang mengetahui jawaban atas pertanyaan yang diajukan. Untuk itu, guru memberitahukan dengan mengucapkan secara lisan dan menuliskannya di papan tulis. Tidak seperti kegiatan sebelumnya dimana guru memberikan tugas kepada siswanya, kegiatan tersebut tidak dilakukan dalam observasi ketiga karena siswa akan melakukan remedial terkait nilai ulangan yang sebelumnya dibagikan. Waktu remedial dilakukan hingga pembelajaran berakhir.

Pada observasi keempat, guru terlihat mengintruksikan siswa untuk mengajukan pertanyaan terkait materi 'kegemaran/kesukaan' yang belum dipahami. Tetapi, siswa tidak ada yang mengajukan pertanyaan terkait materi yang telah dijelaskan oleh guru. Kemudian, guru langsung memberikan tugas yang seperti biasa dilakukan guru kepada siswanya ketika tidak ada siswa yang bertanya. Tugas yang diberikan guru serupa dengan observasi sebelumnya yaitu membuat kalimat berkaitan dengan materi 'kegemaran/kesukaan'.

Kegiatan menanya menanya memang belum secara maksimal, walaupun guru tetap berupaya agar siswa dapat memahami penjelasan materi yang diberikan. Berdasarkan wawancara, rendahnya keinginan siswa bertanya dipicu karena kemauan siswa dalam mengajukan pertanyaan dalam bertanya masih setengah-setengah dan mulai menurun. Guru membandingkan bahwasannya siswa yang sebelumnya pernah diajarkan (siswa angkatan lama) lebih banyak bertanya setelah guru menjelaskan materi.

Berdasarkan hasil observasi yang dilakukan sejak observasi pertama hingga keempat, didapatkan hasil bahwasannya guru tidak melakukan kegiatan mengolah informasi/mencoba sesuai dengan Kurikulum 2013. Kegiatan guru hanya terbatas pada menjelaskan materi, bertanya atau ditanya, memberikan tugas dan mengerjakan tugas yang diberikan guru di papan tulis. Guru menyatakan dalam wawancara bahwasannya yang menjadi poin penting adalah mengajar dan membuat siswanya paham akan materi yang dijelaskan. Tentunya semua itu dikondisikan sesuai dengan kondisi siswa kelas X IPB.

Kegiatan menalar juga belum dapat dilakukan guru karena guru belum dapat menyesuaikan dengan kondisi MAN X yang berlokasi di pedesaan. Guru mengklaim bahwasannya kegiatan mengasosiasi/menalar lebih cocok diterapkan di sekolah yang kondisinya lebih mendukung seperti perkotaan. Sama halnya dengan kegiatan mengolah 
informasi/mencoba, guru menyatakan bahwa mengajar sesuai dengan kondisi siswa akan memudahkan siswa dalam memahami pembelajaran. Guru menyampingkan kegiatan mengolah informasi/mencoba dan mengasosiasi/menalar dan lebih fokus dengan cara bagaimana agar siswa paham akan materi yang dijelaskan.

Kegiatan mengomunikasikan pada umumnya menggunakan cara presentasi. Tetapi pada saat observasi dilakukan, guru menggunakan cara mengintruksikan siswa untuk menuliskan jawaban atas tugas yang telah diberikan ketika guru selesai menjelaskan materi pembelajaran. Beberapa siswa terlihat antusias dalam menjawab tugas yang diberikan, walaupun tidak semua jawaban yang dituliskannya di papan tulis benar. Tetapi siswa sudah memberanikan diri menjawab dan nantinya guru akan mengkoreksi jawaban siswa.

Pada observasi pertama, kegiatan mengomunikasikan dilakukan dengan mengintruksikan siswa sebanyak lima orang untuk maju ke depan. Siswa menuliskan jawaban yang telah dibuat dari tugas membuat kalimat tentang kata kerja.

Observasi kedua, guru masih melakukan cara yang sama seperti observasi yang sebelumnya dilakukan. Guru mengintruksikan siswa untuk maju ke depan dan menuliskan jawabannya dipapan tulis. Penelitian yang dilakukan dapat dilihat bahwa hanya tiga orang siswa yang mau menjawab tugas yang diberikan guru.

Selanjutnya, pada observasi ketiga, guru tidak melakukan kegiatan mengamati karena waktu tersebut digunakan untuk mengadakan remedial. Observasi keempat, berdasarkan tugas yang diberikan tentang 'kegemaran/kesukaan', guru menunjuk empat siswa untuk maju dan menuliskan jawabannya.

Kesimpulan yang dapat diambil dari observasi penelitian yang telah dilaksanakan, guru memang belum melaksanakan kegiatan 5M dalam pendekatan saintifik Kurikulum 2013 secara keseluruhan. Kegiatan yang dilakukan guru guna membuat siswanya paham akan materi yang dijelaskan patut diapresiasi karena guru menggunakan caranya sendiri untuk membuat siswa paham. Karena keterbatasan dan berbagai problematika yang dihadapi, guru merasa lebih nyaman menggunakan caranya sendiri.

Berdasarkan hasil wawancara, kegiatan yang dilakukan saat kegiatan penutup adalah melakukan pengulangan materi dan memberika tugas/pr kepada siswa. Hasil wawancara sudah disesuaikan dengan apa yang terjadi dilapangan. Sehingga dengan melakukan penyesuaian antara observasi dan wawancara, hasil penelitian dapat dipertanggung jawabkan dengan baik.

Hampir keseluruhan observasi, kegiatan penutup dilakukan dengan melakukan refleksi terhadap kegiatan pembelajaran dengan cara mengulang kembali pembelajaran yang ditelah dilakukan, guna mengukur sejauh mana pemahaman siswa. Perbedaanya adalah pada observasi kedua, guru mengingatkan siswanya bahwa pada pembelajaran selanjutnya akan mengadakan remedial. Pada observasi ketiga, kegiatan penutup tidak dilaksanakan karena terbentur kegiatan remedial yang dilakukan hingga pembelajaran berakhir.

Kedepannya guru harus berusaha memahami dan belajar tentang pembelajaran yang berkaitan dengan pendekatan saintifik Kurikulum 2013. Menyesuaikan komponen satu dengan yang lainnya seperti RPP dengan Tema, RPP dengan pembelajaran dan antara RPP, Pembelajaran dengan Evaluasi. pemerintah telah merancang sedemikian rupa terstrukturnya segala komponen untuk mempermudah guru dalam mengimplementasikan pendekatan saintifik Kurikulum 2013. Menjadi tugas gurulah menjalankan dengan semaksimal mungkin.

Dalam mengimplementasikan pendekatan saintifik Kurikulum 2013, diperlukan bahan ajar yang sesuai dengan tuntunan Kurikulum 2013 untuk mendukung suksesnya pembelajaran. Bahan ajar yang baik juga menentukan kualitas pemahaman siswa akan materi yang dipelajarinya. Bahan ajar yang digunakan juga harus sesuai antara RPP yang sudah berbasis Kurikulum 2013 sebagai pedoman dalam pembelajaran.

Berdasarkan hasil wawancara, guru menggunakan bahan ajar berupa buku sakura 1, 2 dan 3 yang digunakannya untuk mengajar siswa kelas X,XI, dan XII IPB di MAN X.

Selanjutnya, peneliti melanjutkan wawancara mengenai cara guru dalam mengevaluasi siswanya. Melakukan evaluasi bertujuan untuk mengetahui sejauh mana pemahaman siswa terhadap materi yang telah dipelajarinya. 
Disebutkan bahwa guru mengevaluasi sesuai dengan Kurikulum 2013 yang meliputi 3 komponen yaitu kognitif, afektif dan psikomotor. Penilaian kognitif diambil dari hasil latihan, psikomotornya dari kegiatan bercakap-cakap. Selain itu, guru juga menilai siswanya dari hasil ulangan harian, tugas dan tanya jawab.

Pendidik dalam menerapkan suatu pembelajaran selalu melakukan segala hal yang diharapkan dapat memberikan dampak positif terhadap anak didiknya. Pendidik dalam mengimplementasikan pendekatan saintifik Kurikulum 2013 diharapkan pula berjalan dengan sempurna sehingga ke depannya siswa merasakan manfaat besar terhadap pembelajaran yang dipelajarinya.

Begitu pula dengan pembelajaran bahasa Jepang yang diharapkan berjalan tanpa problematika apapun. Namun, dalam mengimplementasikan pendekatan saintifik Kurikulum 2013 dalam pembelajaran bahasa Jepang pastinya selalu ada kendala/problematika yang diharapkan dapat menjadi acuan untuk melakukan perbaikan dalam menjalankan pembelajaran di kemudian hari. Untuk mengatasi kendala/problematika tersebut, diharapkan guru dapat mencari upaya, solusi/jalan keluarnya.

Guru terkendala alat dan bahan pembuatan RPP serta terkendala penguasaan teknologi dan biaya yang harus dikeluarkan jika menyuruh orang lain untuk membuat RPP. Guru berinisiatif meminta RPP dari SMAN $X$ yang diadaptasi dan disesuaikan dengan kondisi siswa di MAN X.

Problematika guru adalah belum memahami arti dan langkah-langkah pendekatan saintifik, guru masih berinisiatif mempelajari pendekatan saintifik dan langkah-langkahnya.

Guru juga belum dapat membuat pembelajaran dengan penggunaan power point karena guru menjelaskan materi dengan alat dan bahan yang sudah dimiliki guru dan tentunya disesuaikan dengan kondisi yang dimiliki siswa. Guru mengganti power point dengan kartu gambar/kartu huruf.

Dalam kegiatan menanya, problem guru adalah belum banyaknya siswa yang berinisiatif untuk bertanya. Untuk itu, guru mengantisipasi agar kegiatan menanya tetap berjalan dengan memberikan pertanyaan kepada siswanya.

Guru juga belum melakukan kegiatan mengolah informasi/mencoba,menalar/mengasosiasi dan mengomunikasi (seperti melakukan presentasi) karena terkendala lokasi yang dirasa guru tidak mendukung pelaksanaan pembelajaran dengan pendekatan saintifik. Guru tidak menjelaskan secara rinci mengenai upaya yang dilakukan dalam wawancara. Namun, guru mengatakan bahwa yang terpenting adalah cara mengajarnya bisa membuat siswa mengerti/paham terhadap pembelajaran. Jenis-jenis kegiatan seperti yang tertera dalam RPP hanya cocok diterapkan di sekolah yang berada di perkotaan.

Dalam tahap evaluasi, guru Sulit menilai pengucapan siswa dalam bahasa Jepang. guru pun mengupayakan dengan mengulangi pelafalan dengan benar, memberi ulangan, tugas dan melakukan tanya jawab.

Guru merasa sudah cukup mengajar dengan buku Sakura 1 untuk kelas 10 walaupun ada bahan ajar yang lain. Namun, kendalanya ada pada siswa yang tidak mempunyai buku pegangan seperti LKS. Guru berusaha memberikan materi dengan tertulis agar siswa bisa menyalin di buku tulis. Sesuai dengan keadaan yang dilihat peneliti saat melakukan observasi di kelas.

\section{Simpulan dan Saran}

Berdasarkan pada hasil penelitian dan pembahasan, maka simpulan dari penelitian ini adalah sebagai berikut.

Problematika yang dihadapi guru dalam perencanaan pembelajaran adalah belum dapat menguasai teknologi dan beban biaya yang harus dikeluarkan guru jika menggunakan jasa orang lain dalam pembuatan RPP, sehingga guru belum bisa membuat RPP secara mandiri. Problematika tersebut di upayakan dengan inisiatif guru untuk mengadaptasi dari sekolah lain yaitu SMAN $X$ yang dijadikan acuan walaupun kegiatan pendekatan saintifik berbeda dengan apa yang diajarkan guru pada kelas X IPB di MAN X.

Problematika juga dihadapi guru dalam implementasi kegiatan saintifik meliputi langkah-langkah $5 \mathrm{M}$ Mengamati, Menanya, Mengolah informasi/Mencoba, Menalar/Mengasosiasi dan Mengomunikasikan. 
Dalam kegiatan evaluasi/penilaian, guru hanya dihadapkan pada sulitnya menilai cara pengucapan siswa dalam bahasa Jepang sehingga guru harus melakukan beragam upaya agar siswa dapat mengucapkan pelafalan bahasa Jepang yang sesuai dan tepat.

Problematika guru lainnya adalah belum pahamnya guru arti dari pendekatan saintifik serta langkah-langkahnya. Guru mengupayakan kedepannya bisa belajar tentang pendekatan saintifik hingga memerlukan guru muda yang lebih mengerti terutama tentang Kurikulum 2013

Dalam mengimplementasikan langkah-langkah pembelajaran dalam pendekatan saintifik terdapat dalam kegiatan mengamati, dimana guru belum menyesuaikan dengan RPP termasuk pembuatan media Power Point yang bisa dicoba guru. Namun, guru belum bisa membuatnya dan lebih memilih menggunakan kartu gambar dan huruf yang dimiliki, walaupun belum semua materi bisa menggunakannya.

Problematika yang dihadapi guru dalam kegiatan menanya adalah belum aktifnya siswa dalam bertanya. Upayanya guru yang memberikan pertanyaan agar siswa turut aktif dalam kegiatan belajar mengajar.

Guru belum melakukan kegiatan mengolah informasi/mencoba, mengasosiasi/menalar dan mengomunikasikan (seperti presentasi) yang dapat disesuaikan dengan RPP yang ada karena terkendala belum mendukungnya lokasi dimana MAN X yang terletak di pedesaan. Upaya yang dilakukan adalah melakukan pembelajaran dan berusaha membuat siswanya paham terhadap materi yang diberikan.

Dalam mengevaluasi/melakukan penilaian, guru hanya kesulitan dalam menilai pengucapan bahasa Jepang yang dilafalkan siswa. Upaya yang dilakukan adalah mengulangi pelafalan tersebut dan meningkatkan mutunya dengan melakukan ulangan, latihan dan tanya jawab.

Problematika terakhir adalah bahan ajar yang lebih tertuju pada LKS yang tidak dimiliki siswanya. Upaya yang dilakukan adalah memberikan materi untuk disalin siswanya sebagai pegangan untuk belajar selain disekolah.

Berdasarkan simpulan, maka saran yang dapat disampaikan oleh peneliti adalah guru hendaknya terus belajar untuk memahami pendekatan saintifik Kurikulum 2013 agar pembelajaran dengan menggunakan pendekatan ini dapat diimplementasikan ke siswanya dengan maksimal. Guru dapat memanfaatkan teknologi terkini yaitu internet untuk mencari bahan rujukan (artikel, Jurnal, e-book dII) tentang pendekatan saintifik Kurikulum 2013. Selain itu, untuk memantapkan pengetahuan guru tentang pendekatan saintifik Kurikulum baik dari tahap perencanaan sampai pada penilaian dengan mengikuti pelatihan maupun seminar baik yang dilakukan sekolah maupun pemerintah.

Cara lainnya adalah berkonsultasi dengan kepala sekolah atau guru yang lebih memahami implementasi pendekatan saintifik Kurikulum 2013. Memberikan motivasi, bimbingan, arahan kepada siswanya tentang pendekatan saintifik agar turut aktif dan andil dalam mensukseskan implementasi pendekatan saintifik yang dilakukan.

\section{Daftar Pustaka}

Muhammedi. 2016. "Perubahan Kurikulum di Indonesia: Studi Kritis Tentang Upaya Menemukan Kurikulum Pendidikan Islam yang Ideal. Serdang, Volume.IV (hlm.49)

Seillariski, Ishlah. 2015. Implementasi Pendekatan Saintifik dalam Pembelajaran Sejarah di SMA Negeri Rembang. Semarang: Unversitas Negeri Semarang

Undang-Undang Republik Indonesia Nomor 20 Tahun 2003 Tentang Sistem Pendidikan Nasional. Jakarta: Departemen Pendidikan Nasional 